\title{
The Existence of Schools as Professional Learning Community (PLC)
}

\author{
A.Furqon, D. Satori, A. Komariah, and A. Suryana \\ Universitas Pendidikan Indonesia, Bandung, Indonesia
}

\begin{abstract}
The main objective of this research was to depict school as professional learning community (PLC) as a way of continuous professional development (CPD). In this research, case study is used with 4 stages namely: (1) pre-field; (2) field work; (3) data analysis, and (4) evaluation and reporting. The findings of this research indicated that the elements of PLC construction covered commitment, responsibility, usefulness, collaboration collegial, as well as school culture and climate. In school, PLC is formed as a parallel group of teachers dealing with formal and informal forms of activities, having coordinators, focusing themes on improving the quality of teaching-learning services, teacher participation, and internal and external sources. The impacts of PLC on teachers included increasing self-reflection and self-renewal capacities, understanding characteristics, developing potentials, and improving the quality of teaching-learning services. Meanwhile, the role of the principal in this PLC was not only as an instructional leader but also as a motivator and a facilitator. The conclusion of this research states that PLC was able to promote CPD which led to the improvement of teaching-learning service quality. Furthermore, this research suggested a reinforcement of PLC characteristics; a need of schools to be PLCs; an improvement of teacher qualified and teaching-learning service; required integration and synergy of internal and external school resources; providing understanding to the teacher by school principal, the development of school's structural and cultural conditions, establishment of cooperation with various parties, and local governments willingness to take a big role in teacher development.
\end{abstract}

\section{Keywords; Professional; Learning; Community;}

\section{INTRODUCTION}

The efforts of increasing the teachers' professionalism are mostly done by the central government while the development of teachers in the regions as well as the schools, are still trying to be involved in the central policy. Therefore, it understandable that the teacher professionalism has not got improvement. Teachers Working Group in a particular cluster is still partial and not yet integrated with the needs of teachers. The activities are often in the form of project-based activities whose main content has not yet been linked with the goal of improving teachers' competence which needs improvement. The teacher's performance appraisal policy is only done to fulfill the administrative requirements. Besides, the teacher's understanding of CPD as an effort to improve the professionalism as a teacher is still very low. Teachers are more interested in the number of credits offered as a reward than the substantial benefits offered by CPD in improving their quality.
Darling-Hammond $(2005,2009)$ states that teachers should be facilitated to be consciously involved in the process of mutual learning and collaboration to solve, through professional learning communities, the real problems that they experience in schools $[3,4]$. The teachers' development should be school-based as it supports the formation of the teacher's community as a learning community and fosters the development of a new desired learning culture. Meanwhile, DuFour \& Eaker (1998) revealed that the most promising strategy for ongoing school quality improvement is by developing the school personnel's ability to function as a professional learning community. There are at least 3 (three) rational needs of school-based and teacher-based professional development:

- The schools know a lot of things related to the competence of teachers teaching in the aforementioned schools

- It becomes more effective and easy activities which can control the attendance and activities

- The accomplishment of the distance and time [8].

This study aimed at completely portraying the elements, organization, and impact of PLC to the teacher performance. In addition, it aimed also at portraying the roles of the principal and the hypothetical model of PLC in primary school. The research approach used in this research was qualitative approach. This qualitative research actually is more specifically directed to the use of case study as the opinion of Lincoln and Guba (1994) who state that qualitative approach can also be called a case study involving in-depth and detailed research on everything related to the subject of the research.

This preliminary study was conducted to find the data of the implementation of PLC characteristics dealing with the potential suspected schools. The researcher determines the school with the following criteria: a) the school has been accredited $\mathrm{A} ; \mathrm{b}$ ) the school belongs to the the top group from national examination ranking; c) the number of the teachers in each study group consists of 2 - 5 people so that it allows collaborative activities in it; d) the headmaster has got his or her master's degree already; e) the school belongs to favorite school categories proven by the achievement of the school as an institution and the interest of parents to send their children to the school; and f) the physical condition of school is good and the school facilities are neat, clean, and well-maintained. Some research instruments were developed to describe PLC through 
learning (Ailwood\&Follers, 2002). The form of PLC in school was manifested in teacher activity group. This group consists of several parallel classes, each of which consisted of 4-6 teachers. In each parallel class, there was one person agreed as the coordinator.

\section{A. The Elements in Forming PLC}

\section{1) Commitment, responsibility, and benefit}

The commitment of the teachers were reflected through their awareness and abilities in positioning themselves as part of the learning community working together with others to improve the learning process in the classroom. The teachers were always encouraged to explore information and knowledge that was important for them as well as became a reference and reflection in developing their professionalism potential as educators. In addition, the teachers recognized that the task of the teacher is not just as a teacher, but also as a learner at the same time.

The teachers recognized that improving the ability and capacity as educators is necessary. This responsibility made the teacher keep improving their professionalism which, furthermore, made the learning community eventually forms as a forum for improving the teachers' professionalism.

In addition, the teachers got benefit from discussing and chatting with other teachers in parallel, both formally and informally. The most important thing was to provide opportunities for teachers to share knowledge, insight, ability, and professional skills, while at the same time established togetherness among all teachers involved.

\section{2) Collegial collaboration}

Teachers shared and complement the appeared shortcomings and discuss them collectively so that there would be collective decision among teachers. Sharing the teaching experience within the community between teachers in the school aimed at enabling teachers, who already joined a particular group, to exchange ideas and teaching experiences, help each other, and also overcome the difficulties encountered in managing teaching and learning activities. The collaborative learning was based on the value of cooperation and collegiality.

\section{3) School climate}

The openness, respect, mutual understanding of obligations, trust and concern among teachers and the atmosphere of kinship in the school were enough to support teachers to perform activities in the school. Basically, school climate played an important role in providing a healthy and positive school environment. The interactions between different schools and classroom climate factors could provide support that allows all members of the school community to teach and learn optimally. A positive school climate was a particular environment which was rich for personal growth and academic success. Moreover, a good school climate made teachers work well because of the demand of the profession, the need to increase its capacity, and the responsibility to work sincerely to give the best service for learners.

\section{B. Organizing PLC}

\section{1) Form}

There was no single standard form of organizing PLC. The form was adapted to the context and community support. Nevertheless, there were similarities dealing with the focus of

\section{2) Time and coordination}

Time is also important aspect for every lesson (Stoll and Earl, 2003; Hopkins, 2001). The activities were held at least once a week. In addition to the agreed schedule, teachers also often exchanged opinions, experiences, and skills by learning with other teachers through chats or talks. It was a formal form of learning community that has been established in schools. Informally, it included a variety of interactions among the unorganized teachers which aimed at achieving teacher professional development. This interaction might occur anywhere, inside or outside school. Another important point in organizing this learning community is the division of tasks in accordance with the field that the teachers have already mastered.

\section{3) Theme}

The theme that discussed in the learning community is about the effort of improving the learning quality. Another theme that is discussed in this community is about the characteristics of students, student differences, and how to handle students. By understanding the characteristics and differences of students then the teacher can provide a good service to each learner in accordance with its characteristics. In addition to lesson planning, learning delivery strategies and classroom organizing are also topics often discussed by teachers. These themes focus on improving the quality of student learning

\section{4) Resource person}

The resource persons from internal schools were the senior the school committee. In addition to empowering internal resource person, the three schools also often involved other sources from outside the school which were still related to the needs of teachers or teachers' difficulties in their field. The outside-school sources included school supervisors, education offices, practitioners or academics in the educational fields in who were in line with their areas of expertise.

\section{5) Teacher participation}

The presence of teachers in community learning activities was one of the important elements in PLC. If there was no teacher presence, this community learning activity would not work as what had been expected. The teachers increasingly had professional competence if they were involved in the teacher working group because all issues related to their teaching and learning activities would be solved with the help of other parties who are competent in their fields.

\section{The Impact of PLC on teacher professional development}

\section{1) Reflection and self-renewal capacity}

Through the learning community, the teachers became more enthusiastic to learn from others as well as to accept peer advice and correct their own shortcomings. Sharing of knowledge in the school created a professional atmosphere among teachers so that teachers were comfortable in their teachers, the principals, the vice principals, and the elements of 
profession. As a result, the teachers improved their quality of learning, both the planning and process as well as the evaluation. In addition, the teachers continuously improved their lesson planning in order to meet the standard of good teaching-learning service which suited the needs and characteristics of the learners. With frequent gathering and discussion, the more frequent teachers shared their knowledge and experiences in the learning process, the more likely it sharpened their ability to plan and to implement good learning process, and to accommodate all the students' needs as well as to handle them who needed more attention from the teachers. Moreover, the teacher's insight increased and enriched their knowledge of learning techniques and also their constraints.

\section{2) Improving the understanding of the characteristics and the potential development of the learners}

The teachers' increased knowledge about the developmental psychology of learners allowed them to have better understanding of what was needed, desirable, and which point would be achieved by the learners. In addition, it could provide services in both classical and individual areas for those who experience difficulties, in balance. Frequently, the teachers found their students have difficulties in receiving lessons at school as in facing obstacles in digesting and absorbing the learning material delivered by the teacher. The implications of the increased knowledge and experience would provide optimal service to the learners.

\section{3) Improving the quality of the teaching-learning service}

Teachers needed to always respond to new and updated knowledge changes, especially those dealing with fresh ideas related to the curriculum implementation in the classroom, so that it led to the learning quality improvement. The high quality of learning would be achieved when teachers met the needs of the students. Furthermore, the ability of teachers to create active and fun learning was a positive effort to improve the quality of learning. The skill was completed by the teacher's maximum effort through applying the 8 basic teaching skills. They are skills for opening and closing lessons, questioning skills, strengthening skills, explaining skills, classroom managing skills, variation skills, small group discussion skills and small group teaching skills. The teachers managed the whole teaching-learning process that could give stimulation to the students so that they were able to learn. Thus, the students could successfully achieve the three domains of learning, namely cognitive, affective and psychomotor. The efforts in creating active and fun learning were done through consistent application of basic teaching skills, and the teachers were able to create improvisation and development for every basic teaching skill.

\section{$D$. The role of the principal in PLC}

\section{1) Instructional leader}

The principals always supported the teacher in their practices. The principals understood that the practice was done through several activities so that it could not only improve the quality of education and learning but also allocate funds to buy books relating to improving the quality of learning. Some principals even attended various quality improvement activities of individual learning practices as well as with teachers, such as workshops, seminars, and trainings. The principals provided excellent service to all students so that they would be able to develop their basic and instrumental potential in order to face the future challenges. Petterson (2002) provides a comprehensive definition of instructional leadership: (1) principals socialized and introduced the content and the meaning of the school's vision; (2) the principals involved some stakeholders in the school management; (3) the principals provided adequate support to the learning process; (4) the principals supervised the teaching and learning process; and (5) the principal took a role as facilitators.

\section{2) Motivator}

The principals acted as teacher's work partner in the teaching and learning process. They formed teacher's morale by providing other incentives when the teacher had completed the work out of the assigned task, and giving rewards to the teacher who accomplished his or her task. The principals were always willing to help teachers identify the learning goals and share ideas and experiences about curriculum and teaching-learning problems. The teachers were given an authority to develop particular syllabi and learning planning. Moreover, the schools allocated funding already so that the activity ran as expected and successfully gave morale to the teacher.

\section{3) Facilitator}

The principals created a climate that encouraged risktaking and eliminated fear of failure. The schools had the capacity to develop a shared vision of what was desired and engagement in various of actions required to realize the shared vision. According to Davis and Thomas (1989), teachers can work together to improve their professionalism through working groups or teams consisting of some teachers who meet every week or every day to solve problems or plan and implement new learning and learning methods [2]. The principals helped everyone in school to gain a better knowledge of the reality. In addition, Senge (1990) states that the organization that will succeed and exist in the future is an organization whose members in it become learners [9]. Hence, to make schools as a goo organization, the school leaders had to accept responsibility for creating conditions that encourage and enhance the teaching and learning process.

\section{CONCLUSION}

The key to the success of a professional learning community in a school were the commitment, motivation, and passion to move forward. Furthermore, in a strong kinship atmosphere and togetherness between teachers who are fully supported by the principals, they would be able to provide the best learning for all students.

This study obtained some specific details of how schools, as professional learning communities, built the teachers' skills in maintaining innovative practices in the teaching and learning. One of the impacts of the professional learning community gained were the increased self-renewal capacity. The other impacts were dealing with increasing knowledge and learning practices among teachers, improving teachers' skills in understanding the characteristics of learners, improving the collaborative process for reflection, and improving the quality of teaching-learning services. All the teachers identified several specific examples to change their practices as a result of their involvement in the professional learning community. It became a proof of the impact of new practice in individual or group context. Thus, it resulted an improvement in the quality of teaching-learning services. 
Moreover, developing activities that had been carried out took extra energy, thoughts, and time to defend it. The ability of the principal was one of the main determinants of the teachers' empowerment and the improvement of qualified process and teaching-learning outcomes. The principals had to be responsible for teachers and school staffs so that all the things could work optimally.

\section{REFERENCES}

[1] J. Ailwood and K. Follers, Developing teacher professional learning communities: The case of Education Queensland. In J. Reid and T. Brown, Challenging Future: Changing Agendas in Teacher Education. Challenging Futures Conference, Armidale, NSW, 14: 3-7, 2002.

[2] G.A. Davis and M.A. Thomas, Effective schools and effective teachers. Allyn \& Bacon, 1989.

[3] L. Darling-Hammond, D.J. Holtzman, et al. Does teacher preparation matter? Evidence about teacher certification, teach for America, and teacher effectiveness. Education Policy Analysis Archives, 13(42): 16$17,20,2005$.

[4] L. Darling-Hammond and N. Richardson, Research Review. Teacher Learning: What Matters? How teachers learn, February 2009, 66 (5): 4653, 2009.

[5] R. DuFour and R. Eaker, Professional learning communities at work: Best practices for enhancing student achievement.Alexandria, VA: Association for supervision and Curriculum Development, 1998.

[6] E.G. Guba and Y.S. Lincoln, Competing paradigms in qualitative research. Handbook of qualitative research, 2: 163-194, 105, 1994.

[7] D. Hopkins and D. Reynolds, The past, present and future of school improvement: Towards the third age, British educational research journal, vol. 27, no.4, pp.459-475, 2001.

[8] Permana, J.Sudarsyah, A. Model pengembangan profesi guru melalui professional learning community di sekolah menengah, Jurnal Administrasi Pendidikan, XXIII(1): 81-90, 2016.

[9] P. M. Senge, The fifth discipline: The art and practice of the learning organization. Performance Instruction (Vol. Rev. and u). http://doi.org/10.1002/pfi.4170300510, 1990.

[10] L. Stoll, D. Fink, and L.M. Earl, It's about learning (and it's about time). Psychology Press, 2003. 